\title{
Endometrial oxytocin binding sites in normal women and in subfertile patients
}

\author{
Philip N. Baker, Meryl L. Peat, E. Malcolm Symonds and Paul V. Maynard \\ Department of Obstetrics and Gynaecology, University Hospital, Queen's Medical Centre, \\ Nottingham NG7 2UH, UK.
}

\begin{abstract}
Summary: Specific binding of oxytocin to high affinity sites in endometrial membrane preparations has previously been shown in sheep. Endometrial tissue preparations from 27 'normal' women of proven fertility were incubated with tritiated oxytocin and the existence of significant binding sites in human endometrium was shown. Furthermore, the level of binding sites underwent a cyclical variation with the highest concentration of binding at midcycle. A cyclical pattern of binding site concentration not unlike that found in the normal women was shown in 19 subfertile patients taking clomiphene.

However, in 20 subfertile patients not taking clomiphene, no cyclical pattern emerged with significantly lower levels of binding sites in the mid-portion of the cycle $(P<0.02)$ and significantly higher levels in the mid-late luteal phase $(P<\mathbf{0 . 0 1})$, as compared to the normal women. In the mid-portion of the cycle levels were significantly lower in the subfertile patients not taking clomiphene $(P<0.03)$ as compared to those taking clomiphene. No significant differences were shown between the normal women and those patients taking clomiphene.
\end{abstract}

\section{Introduction}

Although one or more causes can now be identified for many cases of subfertility, there remains a substantial proportion of patients whose primary subfertility is unexplained. ${ }^{1}$ It is possible that some of these women may have subtle defects in the endometrium that do not enable the tissue to respond adequately to hormones secreted by normally functioning ovaries. Indeed, a defect in the ability of cells to take up progesterone into the nucleus $^{2}$ and a significantly lower level of cytoplasmic progesterone receptors have been described in endometrium from such women. ${ }^{3}$ Progesterone receptor synthesis is a product of normal oestradiol activity, and it has been shown in rabbit uterine tissue that synthesis of specific binding sites for oxytocin is also stimulated by oestradiol, and repressed by progesterone. ${ }^{4}$

Oxytocin is produced and secreted by the posterior pituitary gland and this is involved, through high affinity binding sites in the mammary glands ${ }^{5}$ and myometrium, ${ }^{6}$ in the processes of lactation and parturition. Recently, however, it has been shown that the corpus luteum, at least in the ewe, is capable of synthesizing oxytocin ${ }^{7}$ and thus may play a role in the normal control of fertility by action on oxytocin receptors which have been found to be present in the endometrium. ${ }^{8}$ Oxytocin

Correspondence: P.N. Baker, B.M.

Accepted: 21 September 1989 has been shown to stimulate the production of luteolytic $\mathrm{PGF}_{2}{ }^{9}$ and during luteal regression in sheep, intermittent surges of $\mathrm{PGF}_{2}$ secretion from endometrium are accompanied by similar surges of plasma oxytocin. ${ }^{10}$ In view of the close relationship of oxytocin receptor concentrations to the steroid hormones, we have studied the binding of oxytocin to endometrial material in both fertile and subfertile women in an attempt to understand more about the role of the peptide hormone in the human.

\section{Patients and methods}

\section{Patients}

Endometrial tissue was obtained by dilatation and curettage from 66 women attending the University Hospital, Nottingham. Normal tissue was obtained from 27 patients admitted for sterilization who had had at least one full-term pregnancy. They were not taking steroidal contraceptives nor using an intrauterine contraceptive device. Tissue was also obtained from 39 patients with primary subfertility. All 39 patients had a normal pelvis at laparoscopy with fallopian tube patency as demonstrated by bilateral spill of dye. Consort's semen analysis was within the laboratory's quoted normal limits. Nineteen of the 39 patients were taking the anti-oestrogen drug clomiphene. In all 66 patients serum oestradiol and progesterone levels were 
consistent with stated day of cycle, as was histological dating of endometrial tissue.

Part of the curettage material was put in formol saline for histological examination, and the remainder frozen at $-20^{\circ} \mathrm{C}$. Peripheral blood was taken from every patient within 24 hours of operation and serum oestradiol and progesterone concentration measured.

\section{Methods}

All procedures were performed at $4^{\circ} \mathrm{C}$.

Oxytocin uptake Endometrial samples were rinsed in ice-cold $0.9 \%(\mathrm{w} / \mathrm{v}) \mathrm{NaCl}$ containing EDTA $(1 \mathrm{mmol} / \mathrm{l})$. The material was then homogenized in $25 \mathrm{mmol} / \mathrm{l}$ tris- $\mathrm{HCl}$ buffer $(\mathrm{pH} \mathrm{7.6)}$ containing $0.25 \mathrm{~mol} / 1$ sucrose and $1 \mathrm{mmol} / \mathrm{l}$ EDTA. Homogenates were centrifuged at $200 \times g$ for 10 minutes, the resulting supernatants being further centrifuged for 1 hour at $95000 \times g$. The pellets obtained were washed with tris- $\mathrm{HCl}$ buffer and then resuspended by homogenization in $500 \mathrm{ml}$ of the same buffer. ${ }^{3} \mathrm{H}$-Oxytocin binding in the subcellular fractions thus produced was measured by incubating $100 \mu \mathrm{l}$ of the fraction at $25^{\circ} \mathrm{C}$ for 15 minutes in $100 \mathrm{ml}$ tris- $\mathrm{HCl}$ buffer containing $0.1 \%(\mathrm{w} / \mathrm{v})$ bovine serum albumin, $2 \mathrm{mmol} / \mathrm{l}$ $\mathrm{MnCl}_{2}$ and $60 \mathrm{nmol} / 1{ }^{3} \mathrm{H}$-oxytocin. Non-specific binding was measured in the presence of $200 \mu \mathrm{mol}$ unlabelled oxytocin. After incubation, $2 \mathrm{ml}$ icecold tris- $\mathrm{HCl}$ buffer containing $1 \%(\mathrm{w} / \mathrm{v})$ bovine serum albumin was immediately added. The particulate fraction was then removed on to fine glass fibre filters and washed twice with $2 \mathrm{ml}$ tris- $\mathrm{HCl}$ buffer containing $0.1(\mathrm{w} / \mathrm{v})$ bovine serum albumin. The filters, containing membrane-bound ${ }^{3} \mathrm{H}$ oxytocin, were then counted in a liquid scintillation counter. The specific binding was calculated from the difference in binding (per mg protein) between the incubation with and without excess oxytocin. The protein in $100 \mathrm{ml}$ of each endometrial sample was measured by the method of Lowry et al. ${ }^{\text {I1 }}$ using bovine serum albumins as standards.

Serum steroids Serum oestradiol and progesterone were measured by specific radioimmunoassays with inter-assay coefficients of variation of $8.8 \%$ and $6.5 \%$ respectively at median concentrations. The normal ranges in the laboratory are: progesterone in the follicular phase $0.32-1.9 \mathrm{nmol} / 1$ and luteal phase $6.4-7.9 \mathrm{nmol}$, oestradiol in the follicular phase $73.4-257 \mathrm{pmol} / \mathrm{l}$, at midcycle $367-1468 \mathrm{pmol} / \mathrm{l}$ and in the luteal phase $184-1101 \mathrm{pmol} / \mathrm{l}$.

Statistical analysis In calculations of statistical significance Fisher's exact probability test was used for binding site concentrations and the Student $t$-test for the serum steroid concentrations.

\section{Results}

The mean ages of the three groups \pm s.e.m. were normal women $33.4 \pm 0.8$ years, subfertile women not taking clomiphene $28.6 \pm 0.6$ years, subfertile women taking clomiphene $28.2 \pm 0.6$ years.

Figures 1 and 2 indicate the serum steroid concentration (mean values \pm s.e.m.) in normal women (N), subfertile patients not taking clomiphene (I) and subfertile patients taking clomiphene (IC). The number of patients in each group is indicated at the base of the respective columns.

The serum oestradiol concentrations of patients in the mid-portion of their menstrual cycle (days 11-18) were found to be significantly higher in patients on clomiphene as compared to normal women $(P<0.001)$ and to subfertile patients not taking clomiphene $(P<0.001)$. Serum oestradiol concentrations in patients on clomiphene were also significantly higher in the mid/late secretory phase of the cycle (days 19-28), as compared to normal women $(P<0.01)$ and to subfertile patients not taking clomiphene $(P<0.001)$. No differences were found in progesterone levels.

Figures 3-5 illustrate the levels of oxytocin binding site concentration plotted against the day of menstrual cycle, defined as time from the beginning of last menstrual period.

When the concentration of oxytocin binding in 'normal' women was compared to that in patients with unexplained primary subfertility not taking

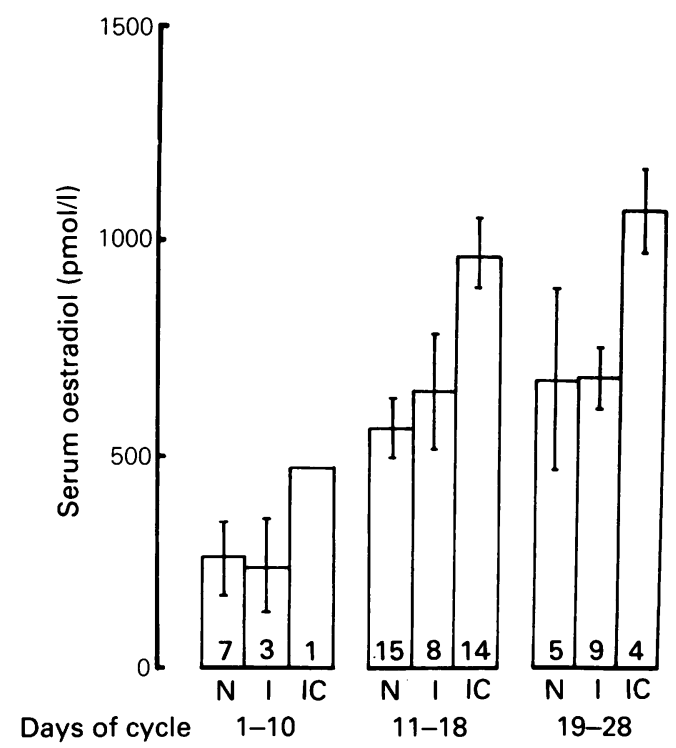

Figure 1 Mean serum oestradiol concentrations \pm s.e.m. in normal women (N), subfertile patients not taking clomiphene (I) and subfertile patients taking clomiphene (IC). Figures at base of column indicate number of patients in each group. 


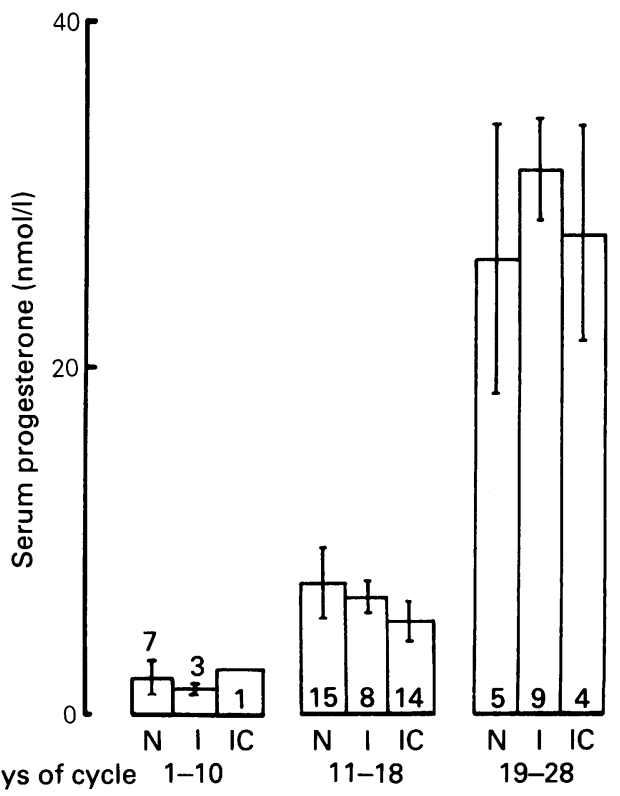

Figure 2 Mean serum progesterone concentration \pm s.e.m. (see Figure 1 for details).

clomiphene, significantly higher levels of binding were found in the mid-portion of the cycle (days $11-18), P<0.01$. Similarly, oxytocin binding in the mid-portion of the cycle (days 11-18) in subfertile patients not taking clomiphene was significantly higher. In the mid/late luteal phase of the cycle significantly higher levels of oxytocin binding were found in subfertile patients not taking clomiphene as compared with the normal women $(P<0.01)$. No significant differences were found between the normal women and the subfertile women taking clomiphene.

\section{Discussion}

The results obtained show that in normal women, the concentration of oxytocin binding sites displays a cyclical variation during the menstrual cycle (Figure 3). The concentration of binding sites was found to be low in the early proliferative phase (around $0.2 \mathrm{nmol} / \mathrm{mg}$ protein) and increased throughout the proliferative phase, reaching a maximum value of almost $4 \mathrm{nmol} / \mathrm{mg}$ protein at midcycle. The level then decreased during the secretory phase, reaching a value of approximately $0.2 \mathrm{nmol} / \mathrm{mg}$ protein during the mid-late secretory phase of the cycle. These findings are similar to those found in sheep endometrium by Roberts $e t$ $a .^{8}$ and Sheldrick and Flint. ${ }^{12}$

Oestradiol and progesterone endometrial binding sites have also been shown to demonstrate a cyclical variation in normal menstruating women, ${ }^{13}$

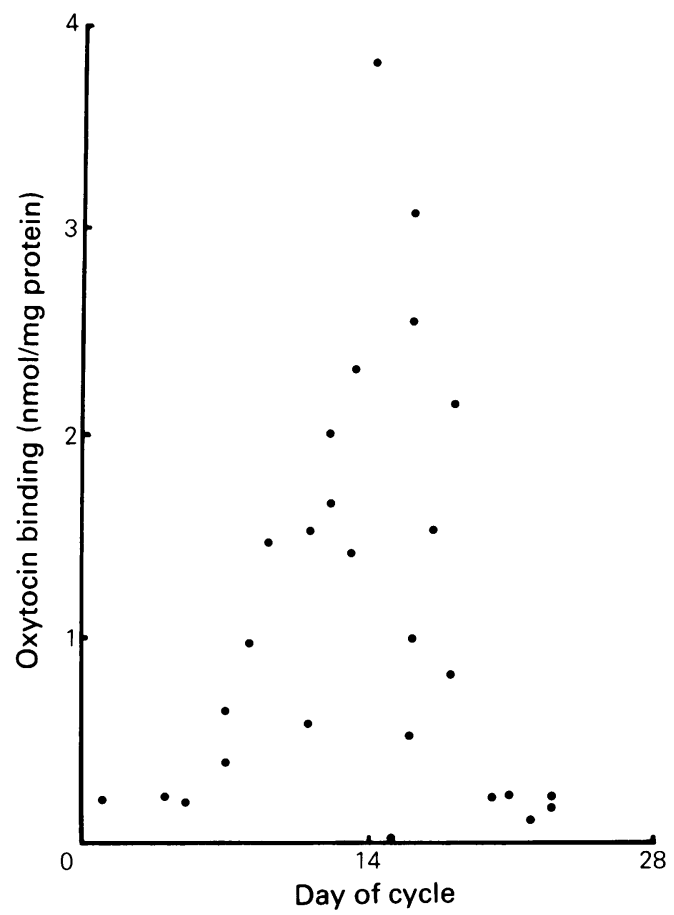

Figure 3 Oxytocin binding sites in endometrial tissue from normal women.

with the high level of oestradiol and progesterone receptors in the late proliferative phase of the cycle correlating with raised levels of oestrogens. It is believed that oestrogens stimulate protein synthesis leading to accumulation of steroid receptors, ${ }^{14}$ and that a raised level of progesterone receptors at mid-cycle is important for implantation. ${ }^{15}$ Depressed levels of both steroid receptors during the secretory phase of the cycle coincide with uterine domination by progesterone which is believed to induce the down regulation of both steroid receptors. $^{16}$

When the group of unexplained primary subfertile women was studied, two distinct patterns of oxytocin binding emerged. It was found that the concentration of binding sites in the subgroup of patients not taking clomiphene did not follow any recognizable pattern (Figure 4) although their plasma steroid concentration differed little from those in the normal group. However, when binding site concentrations in the subgroup of patients taking clomiphene were examined, a cyclical pattern not unlike that in the normal group was found (Figure 5).

Clomiphene therapy to subfertile women is derived from significantly increased pregnancy rates in women so treated. ${ }^{17}$ Fleming and Coutts ${ }^{18}$ found that clomiphene increased follicular development as indicated by elevated pre-ovulatory plasma oestrogen levels, but that this was not 


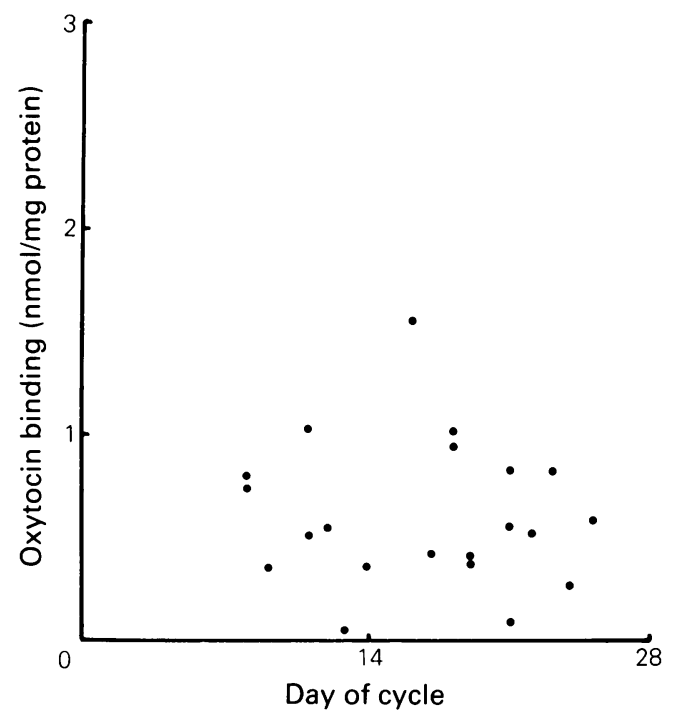

Figure 4 Oxytocin binding sites in endometrial tissue from subfertile patients not taking clomiphene.

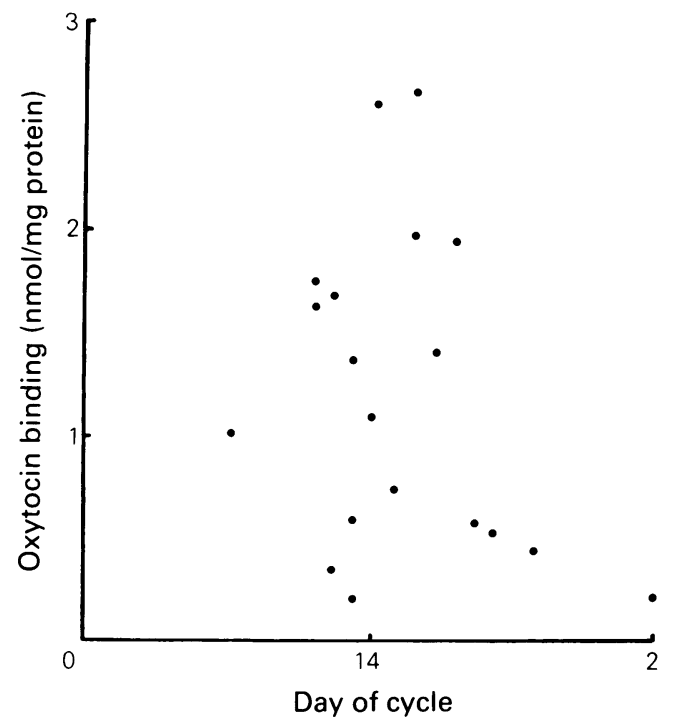

Figure 5 Oxytocin binding sites in endometrial tissue from subfertile patients taking clomiphene.

followed by increased progesterone concentrations. Figures 1 and 2 illustrate how plasma oestradiol levels are significantly elevated in patients taking clomiphene, whereas any difference in plasma progesterone is slight.

When the patients in the unexplained subfertile group are examined, there were no identifiable differences between the two subgroups which might have accounted for the altered oxytocin binding, apart from the use of clomiphene resulting in elevated plasma oestradiol. Patient ages differed minimally when the two sub-groups were compared and the entry-criteria were fulfilled in each case; no differences were found when histology of the endometrial tissue was compared. The concept that oestrogens stimulate oxytocin receptor synthesis ${ }^{9}$ is thus supported; furthermore, clomiphene seems to be able to elicit a cyclical variation in endometrial oxytocin binding site concentration in subfertile patients who otherwise show no such variation. Maynard et al. ${ }^{2}$ found that three subfertile patients taking clomiphene had levels of progesterone binding similar to that of the normal group. Women with unexplained primary subfertility are frequently subjected to some form of ovarian stimulation therapy of which the most common is follicular phase anti-oestrogens such as clomiphene citrate. ${ }^{19}$ The reasons for this kind of therapy are unclear, since no menstrual or ovulatory disorder has been diagnosed, and a restoration of hormone binding site concentrations to normal cyclical variation may provide some form of mechanism of action.

Pliska et al. ${ }^{20}$ suggested that at least three binding site populations exist in the myometrium and endometrium of sheep, calves and rats. If the same is true of human endometrial tissue possibly only one population of binding sites was being sampled in this study. The binding sites in subfertile patients may thus differ in nature rather than in number.

The experimental errors in dealing with such small tissue samples were considerable. Only two pieces of tissue were large enough to permit duplicate assays - the values were 1.24 and $0.93 \mathrm{nmol} / \mathrm{mg}$ protein for one tissue and 0.14 and $0.40 \mathrm{nmol} / \mathrm{mg}$ protein for the other. Nevertheless, the altered oxytocin binding site levels demonstrated in the study may well have future implications when considering the aetiology of and management of primary, unexplained subfertility.

\section{References}

1. Templeton, A.A. \& Penney, G.C. The incidence, characteristics and prognosis of patients whose infertility is unexplained. Fertil Steril 1982, 37: 175-182.

2. Maynard, P.V., Baker, P.N., Symonds, E.M., Sant-Cassia, L.J., Johnson, J. \& Selby, C. Nuclear progesterone uptake of endometrial tissue in cases of subfertility. Lancet 1983, ii: $310-312$.

3. Sant-Cassia, L.J., Symonds, E.M., Johnson, J., Selby, C. \& Maynard, P.V. Progesterone and oestradiol binding in the cytosol of endometria from fertile and subfertile women. Infertility 1987, 10: 1-14.

4. Nissenson, R., Flouret, G. \& Hechter, O. Opposing effects of estradiol and progesterone on oxytocin receptors in rabbit uterus. Proc Natl Acad Sci USA 1978, 75: 2044-2048. 
5. Soloff, M.S., Rees, H.D., Sar, M. \& Stump, W.E. Autoradiographic localisation of radioactivity from $\left[{ }^{3} \mathrm{H}\right]-$ oxytocin in the rat mammary gland and oviducts. Endocrinology 1975, 96: 1475-1477.

6. Soloff, M.S., Swartz, T.L. \& Steinberg, A.H. Oxytocin receptors in human uterus. J Clin Endocrinol Metab 1974, 38: 1052-1056.

7. Flint, A.P.F. \& Sheldrick, E.L. Ovarian secretion of oxytocin in sheep. J Physiol 1982, 330: 61-62.

8. Roberts, J.S., McCracken, J.A., Gavagan, J.E. \& Soloff, M.S. Oxytocin-stimulated release of prostaglandin $F_{2}$ from ovine endometrium in vitro. Endocrinol 1976, 99: 1107-1114.

9. Sharma, S.C. \& Fitzpatrick, R.J. Effect of oestradiol 17 and oxytocin treatment on $\mathrm{PGF}_{2}$ release in the anoestrous ewe. Prostaglandins 1974, 6: 97-105.

10. Fairclough, R.J., Moore, L.G., McGowan, L.T. et al. Temporal relationship between plasma concentrations of 13,14-dihydro-15-keto-prostaglandin F and neurophysin I/II around luteolysis in sheep. Prostaglandins 1980, 20: 199-208.

11. Lowry, O.H., Rosebrough, N.J., Farr, A.L. \& Randall, R.J. Protein measurement with the Folin phenol reagent. $J$ Biol Chem 1951, 193: 265-275.

12. Sheldrick, E.L. \& Flint, A.P.F. Endocrine control of uterine oxytocin receptors in the ewe. $J$ Endocrinol 1985, 106: 249-258.

13. Levy, C., Robet, P., Gautray, J.P. et al. Estradiol and progesterone receptors in human endometrium. Am J Obstet Gynecol 1980, 136: 646-651.
14. Leavitt, W.W., Chen, T.J., Allen, T.C. \& Johnston, J.O. Regulation of progesterone receptor formation by oestrogen action. Ann NY Acad Sci 1977, 286: 210-215.

15. Gautray, J.P., Mortel, R., Robel, P. \& Baulieu, E.E. Uterine receptors and fertility regulation. Acta Eur Fertil 1980, 11: 185-198.

16. Isotalo, H., Isomaa, V. \& Janne, O. Replenishment and properties of cytosol progesterone receptor in rabbit uterus after multiple progesterone administration. Endocrinol 1981, 108: $868-873$.

17. Drake, T.S., Tredway, D.R. \& Buchanon, G.C. Continued clinical experience with an increasing dosage regime of clomiphene citrate administration. Fertil Steril 1978, 30: 274-277.

18. Fleming, R. \& Coutts, T.R. Effects of clomiphene treatment on infertile women with normal menstrual cycles. Br JObstet Gynaecol 1982, 89: 749-753.

19. Greenblatt, R.B. The chemical induction of ovulation. In: Givens, J.R. (ed.). The Infertile Female. Year Book Medical Publishers, Chicago, 1978, pp. 414-437.

20. Roberts, J.S., Barcikowski, B., Wilson, L., Skarnes, C. \& McCracken, J.A. Hormonal and related factors affecting the release of prostaglandin $F_{2}$ from the uterus. J Steroid Biochem 1975, 6: 1091-1097.

21. Pliska, V., Heiniger, T., Müller-Lhotsky, A., Pliska, P. \& Ekberg, B. Binding of oxytocin to uterine cells in vitro. J Biol Chem 1986, 261: 16984-16989. 